neofilolog

Czasopismo Polskiego Towarzystwa Neofilologicznego

ISSN 1429-2173, elSSN 2545-3971, 2021, NR 56/2, 307-319

http://dx.doi.org/10.14746/n.2021.56.2.9

http://poltowneo.org/

Iwona Kowal

Uniwersytet Jagielloński

https://orcid.org/ 0000-0003-4611-2238

iwona.kowal@uj.edu.pl

\title{
Modalizatory jako wielowymiarowe zagadnienie w nauce języka szwedzkiego
}

\section{Sentence adverbials as a multidimensional issue in learning Swedish}

Sentence adverbials build a multidimensional constituent in many languages, i.e. they can, among others, modify the meaning of the entire sentence, emphasize a particular element in it, or build the coherence in texts. Due to the multifaced character of this linguistic phenomenon the acquisition of it in foreign language learners can be a complex process. The learner is not only faced with a variety of different words and phrases that can be used in order to deliver a complementary information in the text, but also, depending on the structural requirements of the specific language, has to learn to put this constituent in the correct place in the sentence. In present paper the use of sentence adverbials in Polish learners od Swedish will be presented. The data considered in the analysis comprises two types of texts: a summary of an expository text and a narrative. The results show that foreign language learners at the intermediate stage of the language use a broad repertoire of sentence adverbials and place them in appropriate contexts. In narratives modal expressions predominate, while in summaries connectives and intensifiers are used more often. The learners can place sentence adverbials correctly in the sentence, especially in main clauses. However, the word order in dependent clauses when other sentence adverbials occur, except for sentences with the negation inte, is still under development.

Keywords: sentence adverbials, foreign language learning, Swedish as a foreign language

Stowa kluczowe: modalizatory, nauka języka obcego, język szwedzki jako obcy 


\section{Wprowadzenie}

W każdej dziedzinie nauki można wskazać zagadnienia, którym poświęca się wiele uwagi, na temat których istnieje wiele opracowań, jak i takie, które znajdują się raczej na peryferiach zainteresowań naukowców. Przyczyn tego można upatrywać w powszechności występowania danego zjawiska, jego stopnia złożoności czy aktualnego zainteresowania badaczy, wynikającego z różnego rodzaju uwarunkowań zewnętrznych. Stopień i zakres zgłębienia danego zagadnienia implikują często różnorodność podejść i terminologii. O ile jednak w przypadku różnych paradygmatów różnice terminologiczne są naturalną konsekwencją, o tyle przy jednorodnych ujęciach zróżnicowanie terminologiczne może prowadzić do konfuzji czy wręcz niemożności wyraźnego wydzielenia danego zjawiska od innych. Jednym z takich zagadnień w językoznawstwie są wyrażenia metatekstowe (zob. Wajszczuk, 2005), w języku polskim funkcjonujące także pod nazwą modulantów (Strutyński, 2002), modalizatorów (Laskowski, 1999), partykuł (M irowicz, 1948; Grochowski i in., 2014), partykułoprzysłówków (Saloni, 1974) czy wyrazków (Szober, 1923). Ich wspólną cechą jest to, że modyfikują treść wypowiedzenia, nie stanowiąc jednocześnie konstytutywnej części zdania, w wyniku czego w tradycyjnych gramatykach często nie były więc ujmowane jako elementy wchodzące w skład zdania. Również (a właściwie przede wszystkim) przy opisie części mowy nie były wydzielane jako osobna klasa wyrazów. Z uwagi na ich różnorodny charakter część trafiała do przysłówków, inne do partykuł, a niektóre do spójników czy wykrzykników. Na problemy terminologiczne tej grupy wyrazów uwagę zwracała m.in. Świątkowska (2014), ukazując rozbieżności w ich nazewnictwie w języku francuskim i polskim. Także na gruncie anglosaskim funkcjonuje kilka terminów określających te jednostki leksykalne. Generalnie traktowane są one jako rodzaj okoliczników (Adverbials) najczęściej nazywane disjuncts. Pojawiają się także określenia 'okoliczniki zdania' (Sentence Adverbials - Biber i in., 1999), 'modyfikatory zdania' (Sentence Modifier - Hartmann, Stork, 1976), 'przysłówki komentujące' (Comment Adverbs - Swan, 2005) czy 'przysłówki zdaniowe' (Sentence Adverbs - Thomson, Martinet, 2001).

Zarówno różnorodność terminologiczna, jak i związana z nią niejednolitość klasyfikacji sprawia, że modalizatory (tego terminu będę używać w dalszej części niniejszego opracowania) mogą stanowić złożone zagadnienie w nauce języka obcego. W niektórych językach bowiem omawiane jednostki językowe, poza heterogenicznością semantyczną, charakteryzują się określoną pozycją, a opanowanie prawidłowego szyku zdania stanowi jedną z najważniejszych umiejętności, koniecznych do skutecznego posługiwania się językiem. W niniejszym artykule zostaną zaprezento wane wyniki badania dotyczącego stosowania 
modalizatorów przez uczących się języka obcego na poziomie średnio zaawansowanym, nazywanych, zgodnie z Europejskim systemem opisu kształcenia językowego (Coste i in., 2003), użytkownikami samodzielnymi. Celem przeprowadzonego badania było uzyskanie informacji, czy uczą cy się używają środków językowych służących modyfikacji treści wypowiedzi i czy potrafią umieszczać je w prawidłowej pozycji w zdaniu z punktu widzenia wymogów formalnostrukturalnych języka obcego. Rozważania w tym zakresie przedstawione zostaną z perspektywy języka szwedzkiego.

\section{Modalizatory w języku szwedzkim jako wielowymiarowe zagadnienie językowe}

Wspomniana powyżej niejednorodność terminologiczna dotycząca modalizatorów w języku polskim czy angielskim występuje także w języku szwedzkim. Wyrazy służące modyfikacji treści zdania określane są nazwą satsadverb (pol. przysłówki zdaniowe), natomiast z punktu widzenia syntaktycznego dla wyrażeń tych stosuje się termin satsadverbial (pol. okoliczniki zdania), obejmujący zarówno przysłówki, jak i wyrażenia wielowyrazowe. Takie rozróżnienie można spotkać w podręcznikach do gramatyki (Holm, Nylund, 1993; Bolander, 2005). W gramatyce języka szwedzkiego Svenska Akademiens grammatik, termin satsadverb jednakw ogóle się nie pojawia. Wyrazy odpowiadające temu terminowi klasyfikowane są jako podgrupy przysłówków (adverb), wyrażających relacje logiczne, postawę nadawcy czy negację. M odalizatory nazywane są każdorazowo satsadverbial i definiowane jako część zdania stanowiąca różnego rodzaju komentarz wypowiedzi zdaniowej (Teleman i in., 1999: 4). Wśród nich wyróżnia się cztery grupy znaczeniowe:

- modulanty (modala satsadverbial),

- konektory (konjunktionella satsadverbial),

- intensyfikatory (fokuserande satsadverbial),

- negacje wewnątrzzdaniowe (negerande satsadverbial).

Podstawową funkcją modulantów jest przekazanie komentarza czy postawy nadawcy wobec wypowiedzenia. Przykładami modulantów w języku szwedzkim są kanske (może, chyba), naturligtvis (oczywiście) czy verkligen (rzeczywiście). Konektory, podobnie jak spójniki, wyrażają relacje logiczne między zdaniami. Zalicza się do nich m. in. därför (dlatego), alltså (zatem), nämligen (mianowicie) czy dessutom (poza tym). Intensyfikatory natomiast podkreślają, uwypuklają dany człon zdania. Wśród modalizatorów tego typu wymienić można bara (tylko, jedynie), just (właśnie), i synnerhet (w szczególności) czy endast (wyłącznie, jedynie). Funkcją negacji wewnątrzzdaniowych jest zaś zaprzeczanie treści wyrażanych przez dany człon zdania. Prototypowym przedstawicielem takich modyfikatorów jest negacja inte (nie), poza tym w tej funkcji występują icke 
czy ej (oba tłumaczone jako 'nie'), które - podobnie jak inte - stanowią negację wewnątrzzdaniową, jednak o wiele węższym zakresie użycia.

O ile w gramatykach szwedzkich nazewnictwo dotyczące modalizatorów jest dość jednorodne, o tyle w podręcznikach do nauki języka szwedzkiego jako drugiego/obcego terminy często nakładają się na siebie czy funkcjonują wymiennie, bez wyraźnego odgraniczenia. W ramach tego samego podręcznika (Levy Scherrer, Lindemalm, 2008; Åström, 2006) bywają nazywane wyrazami łączącymi (sambandsord), wyrazkami (småord), przysłówkami zdaniowymi (satsadverb) czy okolicznikami zdania (satsadverbial). Co ciekawe, do tej grupy wyrazów autorzy zaliczają także typowe przysłówki czasu aldrig (nigdy) i alltid (zawsze). Jest to prawdopodobnie związane z inną cechą charakteryzującą modalizatory w języku szwedzkim, mianowicie z pozycją w zdaniu. Język szwedzki jest językiem pozycyjnym, dopuszczającym jedynie niewielką swobodę zmiany miejsca określonych członów zdania. Stałą pozycją modalizatorów jest środek zdania (mittfält). ${ }^{1}$ M iejsce modalizatorów w ramach tej pozycji w stosunku do podmiotu i orzeczenia (lub jego części finitywnej w przypadku orzeczenia złożonego) zmienia się jednak w zależności od rodzaju zdania. W zdaniach oznajmujących zaczynających się od podmiotu modalizatory znajdują się bezpośrednio po orzeczeniu (lub jego formie finitywnej przy orzeczeniu złożonym). W zdaniach, w których podmiot nie znajduje się na początku (w tym w zdaniach pytających), modalizator umieszcza się po podmiocie, przy czym konieczne jest dokonanie inwersji - orzeczenie (lub jego finitywna część) znajduje się wów czas przed podmiotem. Może być ponadto tak, że modalizator (najczęściej konektor) umieszczany jest na początku zdania i wówczas ewentualny drugi modalizator także zajmuje miejsce po orzeczeniu i podmiocie. Jeszcze inną pozycję modalizatory przyjmują w zdaniach podrzędnie złożonych, gdzie prototypowo umieszcza się je po podmiocie, ale przed orzeczeniem (w formie finitywnej). Dochodzi wówczas do operacji zwanej 'anulowaniem inwersji'.

W uproszczeniu można więc stwierdzić, że modalizatory (M), w zależności od rodzaju zdania, mogą tworzyć trzy podstawowe konstelacje pozycji z podmiotem (P) i orzeczeniem (O): POM, OPM i PM O. Ta cecha modalizatorów powoduje, że bywają one także nazywane 'wędrującymi przysłówkami' (vandrande adverb) czy 'ruchomymi przysłówkami' (rörliga adverb) (Holm, Nylund, 1993; Lindholm, 1997). ${ }^{2}$ Poglądowy schemat zdań z miejscem modalizatorów w języku szwedzkim przedstawia Tabela 1.

\footnotetext{
${ }^{1}$ Wyjątkiem są intensyfikatory, które mogą podkreślać różne części zdania, w zdaniach pojedynczych sytuowane są bezpośrednio przed uwypuklanym członem. Niektóre pojedyncze modalizatory (np. kanske) mogą zajmować także inne pozycje w zdaniu.

${ }^{2}$ Wspomniane powyżej przysłówki czasu aldrig (nigdy) i alltid (zawsze), pojawiają się w podręcznikach i gramatykach jako modalizatory (wędrujące przysłówki) być może
} 
M odalizatory jako wielowymiarowe zagadnienie w nauce języka szwedzkiego

\begin{tabular}{|c|c|c|c|c|c|c|}
\hline \multirow{4}{*}{$\begin{array}{l}\text { Zdanie } \\
\text { pojedyncze } \\
\text { oznajmujące }\end{array}$} & $\begin{array}{c}\text { POZYCJA } \\
\text { INICJALNA }\end{array}$ & \multicolumn{3}{|c|}{$\begin{array}{l}\text { POZYCJA } \\
\text { ŚRODKOWA }\end{array}$} & \multicolumn{2}{|c|}{$\begin{array}{l}\text { POZYCJA } \\
\text { KOŃCOWA }\end{array}$} \\
\hline & Podmiot & $\begin{array}{l}\text { Orzeczenie } \\
\text { I (czas. } \\
\text { w formie } \\
\text { finitywnei) }\end{array}$ & Modalizator & & $\begin{array}{l}\text { Orzeczenie II } \\
\text { (czas. } \\
\text { w formie } \\
\text { niefinitywnei) }\end{array}$ & $\begin{array}{l}\text { Dopełnienie } \\
\text { Orzecznik, } \\
\text { Okolicznik }\end{array}$ \\
\hline & Dopełnienie & Orzeczenie & & & Orzeczenie II & \\
\hline & $\begin{array}{l}\text { Orzecznik } \\
\text { Okolicznik } \\
\text { Modalizator }\end{array}$ & $\begin{array}{l}\text { I (czas. } \\
\text { w formie } \\
\text { finitywnej) }\end{array}$ & Podmiot & Modalizator & $\begin{array}{l}\text { (czas. } \\
\text { w formie } \\
\text { niefinitywnej) }\end{array}$ & \\
\hline $\begin{array}{l}\text { Zdanie } \\
\text { pytające } \\
\text { dopełniające }\end{array}$ & Zaimek pytajny & $\begin{array}{l}\text { Orzeczenie } \\
\text { I (czas. } \\
\text { w formie } \\
\text { finitywnej) }\end{array}$ & Podmiot & Modalizator & $\begin{array}{l}\text { Orzeczenie II } \\
\text { (czas. } \\
\text { w formie } \\
\text { niefinitywnej) }\end{array}$ & $\begin{array}{l}\text { Dopełnienie } \\
\text { Orzecznik, } \\
\text { Okolicznik }\end{array}$ \\
\hline $\begin{array}{l}\text { Zdanie } \\
\text { pytające } \\
\text { rozstrzygające }\end{array}$ & $\begin{array}{l}\text { Orzeczenie } \\
\text { I (czas. w formie } \\
\text { finitywnej }\end{array}$ & Podmiot & Modalizator & & $\begin{array}{l}\text { Orzeczenie II } \\
\text { (czas. } \\
\text { w formie } \\
\text { niefinitywnej) }\end{array}$ & $\begin{array}{l}\text { Dopełnienie } \\
\text { Orzecznik, } \\
\text { Okolicznik }\end{array}$ \\
\hline $\begin{array}{l}\text { Zdanie } \\
\text { podrzędne }\end{array}$ & $\begin{array}{l}\text { Wskaźnik zespo- } \\
\text { lenia (spójnik) }\end{array}$ & Podmiot & Modalizator & $\begin{array}{l}\text { Orzeczenie } \\
\text { I (czas. } \\
\text { w formie } \\
\text { finitywnej) }\end{array}$ & $\begin{array}{l}\text { Orzeczenie II } \\
\text { (czas. } \\
\text { w formie } \\
\text { niefinitywnej) }\end{array}$ & $\begin{array}{l}\text { Dopełnienie } \\
\text { Orzecznik, } \\
\text { Okolicznik }\end{array}$ \\
\hline
\end{tabular}

Tabela 1: Ogólny schemat szyku zdania szwedzkiego (opracowanie własne).

Niejednorodność formalno-strukturalna modalizatorów może stanowić trudność w nauce języka obcego, gdyż uczeń, wraz z rozwojem umiejętności językowych, kilkakrotnie musi dokonywać zmian w uczeniu się zasad odnoszących się do jednego zagadnienia (szyku zdania). Odzwierciedla się to w stopniach opanowania struktur językowych zgodnie z teorią przetwarzania struktur morfosyntaktycznych (Processability Theory), gdzie umiejętności zastosowania inwersji w zdaniu pojedynczym i prawidłowego, prewerbalnego umieszczenia negacji wewnątrzzdaniowej inte w zdaniu podrzędnym nabywane są najpóźniej (Pienemann, Håkansson, 1999).

M odalizatory jako zjawisko wielowymiarowe, zarówno z punktu widzenia semantycznego jak iformalno-strukturalnego, stanowią więc bardzo ważne zagadnienie w nauce języka szwedzkiego. Ich umiejętne zastosowanie w tekście może świadczyć o opanowaniu struktury języka (prawidłowego szyku zdania), umiejętności tworzenia spójnego tekstu (dzięki zastosowaniu konektorów) czy nadania mu indywidualnego charakteru (np. dzięki użyciu modulantów czy intensyfikatorów). Stąd zasadne wydaje się zbadanie poziomu opanowania modalizatorów przez uczniów znajdujących się na średnio zaawansowanym poziomie językowym (B1 - B2 zgodnie z ESOKJ), gdzie zakłada się, że

właśnie z uwagi na ich specyficzną pozycję w zdaniu. Nie umieszcza się ich bowiem (jak pozostałych wyrażeń pełniących funkcję okoliczników czasu) w pozycji końcowej zdania, lecz w miejscu prototypowo przeznaczonym dla modalizatorów. 
potrafią łączyć zdania, tworząc spójne i poprawne gramatycznie wypowiedzi (Coste i in., 2003: 33, 36-37).

\section{Modalizatory w języku szwedzkim jako języku obcym - opis badania}

Choć modalizatory stanowią niezwykle ważne zagadnienie, nie były one dotychczas szeroko badane w kontekście nauki języka szwedzkiego. Istnieje wiele prac poświęconych szykowi zdania, gdzie znaczące miejsce zajmuje negacja inte, będąca wprawdzie modalizatorem, ale omawianym z punktu widzenia operacji anulowania inwersji, tj. prawidłowego umieszczenia negacji w zdaniu podrzędnym (Hyltenstam, 1978; Bolander, 1988). Powstały także opracowania dotyczące użycia konektorów przez uczniów uczących się języka szwedzkiego jako obcego (Vaakanainen, 2018; Lindström, Lubinska, 2019), w tych badaniach modalizatory pełniące funkcję konektorów nie były jednak omawiane odrębnie, lecz wraz z innymi spójnikami.

W niniejszym opracowaniu zostanie podjęta próba opisu użycia modalizatorów przez osoby uczące się języka szwedzkiego, z uwzględnieniem wielowymiarowości tego zagadnienia. Badanie przeprowadzono wśród studentów filologii szwedzkiej po ich dwóch latach nauki języka, czyli po około 570 godzinach, przy czym oprócz zajęć z praktycznej nauki języka studenci uczestniczyli w tym okresie także w innych, typowych dla filologii zajęciach, w trakcie których mieli możliwość rozwoju umiejętności językowych (fonetyka szwedzka, gramatyka opisowa języka szwedzkiego, historia literatury szwedzkiej itp.). Przeprowadzenie badania na grupie studentów po drugim roku studiów filologicznych pozwala więc założyć, że osiągnęli oni poziom B1+według Europejskiego systemu opisu kształcenia językowego (Coste i in., 2003), czyli powinni tworzyć gramatycznie poprawne i spójne teksty.

Uczestnicy badania stanowili stosunkowo homogeniczną grupę: wszyscy byli dorosłymi (w okresie badania 21-23-letnimi) rodzimymi użytkownikami języka polskiego z zaawansowaną znajomością języka angielskiego lub niemieckiego ${ }^{3}$. Należy przy tym dodać, że nikt z uczestników przed rozpoczęciem studiów nie znał języka szwedzkiego. Badania przeprowadzono w dwóch grupach, każda z nich liczyła po 16 osób. Grupy otrzymały różne zadania. Pierwsza grupa została poproszona o napisanie opowiadania na temat Przygoda na wakacjach, natomiast druga grupa - o streszczenie tekstu informacyjnego na

${ }^{3}$ Za zaawansowaną znajomość języka angielskiego/niemieckiego uznano bardzo wysoki wynik egzaminu dojrzałości na poziomie rozszerzonym, na podstawie którego kandydaci zostali przyjęci na studia. Zuwagi na duże zainteresowanie filologią szwedzką (powyżej 10 kandydatów na miejsce) przyjmowani są wyłącznie kandydaci z najlepszymi wynikami. 
temat emotikonów, zamieszczonego w popularnonaukowym czasopiśmie Språket. Należy przy tym zaznaczyć, że choć streszczenia powstały w oparciu o tekst, nie miał on charakteru ciągłego, lecz stanowił formę wywiadów przeplatanych krótkimi informacjami i komentarzami autora. M odalizatory, jakie się w nim pojawiły, występowały w związku ztym stosunkowo rzadko i były to jedynie te najbardziej powszechne, jak negacja inte, intensyfikator bara (tylko, jedynie), modulant egentligen (właściwie) czy konektory dessutom (poza tym) i därför (dlatego). Studenci nie mogli kopiować konstrukcji językowych, do czego się zresztą zastosowali.

Zamysłem takiego skonstruowania badania było uzyskanie dwóch rodzajów tekstów, w celu porównania, czy i w jaki sposób gatunek tekstu wpływa na użycie określonych modalizatorów. Założono, że w tekstach narracyjnych będzie się pojawiało więcej modulantów, jednostek przekazujących postawę nadawcy wobec komunikatu i nadających tekstowi indywidualnego charakteru, podczas gdy w streszczeniu spodziewać się można częstszego użycia konektorów, a rzadszego - modulantów czy intensyfikatorów.

\section{Analiza materiału}

W zebranym materiale wystąpiło łącznie 309 modalizatorów. Streszczenia były dłuższe niż opowiadania, pojawiło się w nich także więcej modalizatorów i były częściej używane (średnio w co drugim zdaniu, w opowiadaniach - w co trzecim). Różnice w długości tekstów tego samego rodzaju nie były duże, natomiast wystąpiły bardzo duże różnice indywidualne w użyciu modalizatorów w opowiadaniach (cv =57\%). W części tekstów niemal w każdym zdaniu pojawiła się jakaś jednostka metatekstowa, w innych natomiast studenci użyli tego typu wyrażeń tylko raz lub dwa razy w całym opowiadaniu. M ożna podejrzewać, że duże różnice indywidualne w zastosowaniu modalizatorów mogły być związane z długością tekstów. Korelacja między liczbą zdań a częstością użycia modalizatorów była wysoka w przypadku opowiadań ( $r=58)$ i przeciętna w streszczeniach ( $r=40$ ), co wskazuje, że im dłuższy tekst, tym częściej występowały w nim modalizatory. Nie jest to jednak wystarczająco silna korelacja, by z całą pewnością można było uznać, że długość tekstu jednoznacznie warunkuje częste zastosowanie tych wyrażeń. Wykonanie testu t studenta pozwoliło stwierdzić, że grupy różnią się od siebie i różnice te są istotne statystycznie $(p \varangle 0,05)$, co może prowadzić do wstępnego wniosku, że rodzaj tekstu może mieć wpływ na częstotliwość użycia modalizatorów.

Dane liczbowe dotyczące ogólnej charakterystyki tekstów znajdują się w Tabeli 2. 
Iwona Kowal

\begin{tabular}{llrrrr}
\hline \multirow{2}{*}{ Zmienna } & Rodzaj tekstu & $\begin{array}{r}\text { Razem } \\
(\Sigma)\end{array}$ & $\begin{array}{r}\text { Średnia } \\
(\mathrm{M})\end{array}$ & $\begin{array}{r}\text { Odchylenie } \\
\text { standardowe }\end{array}$ & $\begin{array}{r}\text { Współczynnik } \\
\text { zmienności }\end{array}$ \\
& & 303 & 18,9 & 4,6 & (cv) \\
Długość tekstów & Opowiadanie & 391 & 24,4 & 6,3 & $26 \%$ \\
(liczba zdań) & Streszczenie & 103 & 0,3 & 0,19 & $57 \%$ \\
\hline \hline Użycie & Opowiadanie & 206 & 0,5 & 0,16 & $30 \%$ \\
modalizatorów & Streszczenie & 203 &
\end{tabular}

Tabela 2: Materiał badań - statystyka opisowa4.

Poszczególne grupy semantyczne modalizatorów były różnie reprezentowane. Jak można było przypuszczać, najczęściej występowały negacje (z kilkoma nielicznymi wyjątkami była to negacja inte), które w obu rodzajach tekstów stanowiły niemal połowę wszystkich użyć. Poza tym zarówno w opowiadaniach, jak i streszczeniach najczęściej używanymi modalizatorami były: konektor också (też) i intensyfikator bara (tylko, jedynie). Duże różnice między tekstami zaobserwowano w przypadku użycia pozostałych modalizatorów. W opowiadaniach pojawiły się 22 różne, a w streszczeniach aż 34 . W tekstach narracyjnych przeważały wyrażenia o konotacji modalnej, przekazujące informację o stosunku nadawcy do danej informacji, takie jak tyvärr (niestety), kanske (może, być może), nog (chyba, raczej). Pojawiło się też sporo konektorów alltså (zatem), ändå (mimo to) czy i stället (zamiast tego). Najmniej użyto intensyfikatorów. Poza wymienionym już wcześniej popularnym bara (tylko) pojedynczo wystąpiły: endast (jedynie, wyłącznie) czy även (nawet). Ten wynik nieco zaskakuje, ponieważ w przypadku opowiadania opisującego osobiste doświadczenia nadawcy, a szczególnie przygodę na wakacjach, można się było spodziewać częstszego występowania wyrażeń uwypuklających poszczególne elementy wypowiedzi.

Rozkład modalizatorów w streszczeniach był zupełnie inny. W tych tekstach przeważały konektory, których było niewiele mniej niż negacji. Konektory były używane nie tylko częściej niż inne rodzaje modalizatorów, lecz stanowiły najbardziej różnorodną grupę. Spośród 18 różnych wyrażeń łączących wypowiedzenia znalazły się zarówno te często stosowane, jak wspomniane już också (też), därför (dlatego), alltså (zatem) czy dessutom (poza tym), jak i te o wiele mniejszej dystrybucji, np. sammanfattningsvis (podsumowując), till att börja med (na wstępie), följaktligen (w następstwie tego, w konsekwencji). W odróżnieniu od opowiadań w streszczeniach często używano intensyfikatorów. Może to wydawać się zaskakujące, lecz przy głębszej analizie materiału okazało się, że jedną czwartą użytych intensyfikatorów stanowiło wyrażenie till exempel (na przykład), które raczej pełni funkcję wyjaśniającą, dopowiadającą niż podkreślającą, choć klasyfikowane jest jako intensyfikator.

${ }^{4}$ Do analizy statystycznej użyto programu STATISTICA 13 
Rozkład poszczególnych grup znaczeniowych modalizatorów w tekstach narracyjnych i streszczeniach przedstawiono na wykresie 1 . Wynika z niego, że rodzaj tekstu ma istotne znaczenie przy wyborze środków modyfikujących komunikat. W opowiadaniach używa się zdecydowanie częściej modulantów, natomiast w streszczeniach - konektorów i intensyfikatorów. Wyniki te pokazują, że studenci na poziomie średnio zaawansowanym potrafią dostosować rodzaj modalizatorów do gatunku tekstu. Wskazuje na to także bardziej wyrównane rozłożenie (poziom wariancji) poszczególnych rodzajów modalizatorów w przypadku tekstów narracyjnych, gdzie różnice w częstości użycia modulantów, intensyfikatorów i konektorów Są o wiele mniejsze $\left(S^{2}=0,003\right)$ niż w streszczeniach $\left(S D^{2}=0,017\right)$, w których użycie modulantów stanowiących odzwierciedlenie osobistego stosunku do wypowiedzi jest wręcz marginalne.

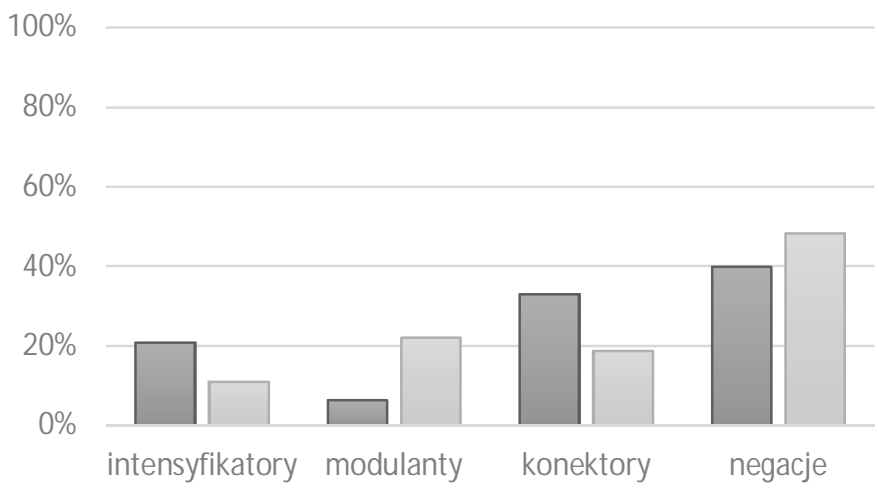

口streszczenie $\square$ opowiadanie

Wykres 1: Dystrybucja grup semantycznych modalizatorów (opracowanie własne).

Poza różnorodnością semantyczną modalizatory charakteryzują się także zmiennością pozycji w zależności od rodzaju zdania. Prawidłowe umieszczenie ich względem pozostałych członów (podmiotu i orzeczenia) jest istotne z punktu widzenia poziomu opanowania języka, który dla studentów kończących drugi rok filologii szwedzkiej, zakładany jest jako B1+. W analizowanym materiale modalizatory używane były przede wszystkim w zdaniach głównych - dwukrotnie częściej niż w zdaniach podrzędnych pojawiały się w streszczeniach i aż trzykrotnie częściej w opowiadaniach. W zdecydowanej większości umieszczano je poprawnie. Odsetek błędnego szyku wyrazów w zdaniach z modalizatorami wyniósł 11\% w przypadku tekstów narracyjnych, a 7\% w tekstach informacyjnych (streszczeniach). M ożna więc uznać, że studenci na średnio zaawansowanym poziomie zasadniczo prawidłowo umieszczają modalizatory 
w zdaniu. W opowiadaniach błędny szyk częściej pojawiał się w zdaniach pobocznych - prawie 3/4 przykładów. W streszczeniach natomiast rozłożenie błędnego szyku zdania z użyciem modalizatora w zdaniach głównych i pobocznych było podobne. Nieprawidłowa kolejność członów zdania w zdaniach głównych występowała w dwóch kontekstach: gdy modalizator (konektor) znajdował się na pozycji inicjującej zdania i wymagana była inwersja oraz gdy zdanie główne wchodziło w skład zdania (wielokrotnie) złożonego. Oznacza to, że długość zdania może mieć istotny wpływ na przetwarzanie szyku wyrazów. Natomiast w każdym przypadku, gdy zdanie główne rozpoczynało się od podmiotu, modalizator zajmował prawidłową pozycję bezpośrednio po czasowniku w formie finitywnej.

W przypadku użycia modalizatorów w zdaniach podrzędnie złożonych, gdzie wymagana jest procedura 'anulowania inwersji', czyli umieszczenia modalizatora w pozycji prewerbalnej, błędny szyk pojawiał się wprawdzie częściej niż w zdaniach głównych, lecz odsetek uchybień był spory tylko w tekstach narracyjnych, gdzie w co trzecim tego typu zdaniu został zastosowany błędny szyk. W streszczeniach nieprawidłowy szyk pojawił się tylko w 10\% takich zdań. W materiałach do nauki języka szwedzkiego szczególną uwagę zwraca się na miejsce negacji inte w zdaniach podrzędnych (por. Kowal, 2020). Pojawia się ona najczęściej w ćwiczeniach i jest wielokrotnie omawiana. Stąd można by wyciągnąć wniosek, że konstrukcjez intew zdaniu podrzędnym będą najlepiej opanowane. Analiza materiału potwierdziła tę hipotezę. Błędny szyk w takich kontekstach wystąpił w niespełna 10\% przypadków. Jeśli jednak w zdaniach podrzędnych znajdowały się inne modalizatory, średnio co drugi umieszczany był na nieprawidłowej pozycji w zdaniu. Pokazuje to, jak ważne jest dostarczenie dużej ilości inputu językowego i ćwiczenie struktur językowych, a także nieskupianie się wyłącznie na jednym czy kilku wybranych elementach języka.

\section{Dyskusja i podsumowanie}

M odalizatory stanowią wielowymiarowe zagadnienie językowe w nauce języka szwedzkiego, gdyż obejmują wiele grup znaczeniowych i zajmują określone (różne) pozycje w zdaniu, dlatego ich przyswojenie może stanowić pewną trudność. W niniejszym opracowaniu przedstawiono wyniki analizy dwóch rodzajów tekstów stworzonych przez studentów filologii szwedzkiej o kompetencjach językowych na poziomie średnio zaawansowanym. Celem badania było sprawdzenie, czy i jak modalizatory wykorzystywane są w różnych typach tekstów - opowiadaniu i streszczeniu - oraz czy umieszczane są w prawidłowym miejscu w zdaniu. Odpowiedź na te pytania miała umożliwić potwierdzenie względnie zaprzeczenie faktu opanowania umiejętności językowych na poziomie średnio zaawansowanym, charakteryzującym samodzielnych użytkowników języka zgodnie z założeniami Europejskiego systemu oceny kształcenia językowego (2003). 
Uzyskane wyniki pozwoliły na wyciągnięcie wniosku, że po dwóch latach nauki języka studenci używają wielu różnych modalizatorów i zasadniczo prawidłowo umieszczają je w zdaniu. Teksty narracyjne znacznie różniły się od streszczeń, jeśli chodzi o częstość użycia i dystrybucję omawianych jednostek leksykalnych. W tekstach narracyjnych modalizatory używane były rzadziej. Tu ujawniły się ponadto znaczne różnice indywidualne: niektórzy uczestnicy badania bardzo często stosowali je w swoich tekstach, u innych występowały raczej rzadko. Rozbieżności te częściowo związane są z długością tekstów - dłuższe teksty najczęściej zawierały więcej modalizatorów. W opowiadaniach częściej używano też modulantów przekazujących informacje o postawie nadawcy względem komunikatu czy komentujących treść wypowiedzenia. Natomiast w streszczeniach takie indywidualnie nacechowane wyrażenia pojawiały się niezmiernie rzadko - przeważały w nich konektory i intensyfikatory. Świadczy to o wysokim poziomie świadomości studentów w zakresie tworzenia tekstu i opanowania przez nich umiejętności odpowiedniego stosowania środków językowych. Na różnice w użyciu modalizatorów w narracjach i streszczeniach mógł mieć także wpływ fakt, że teksty narracyjne były całkowicie dow olne (poza samym tematem) - uczestnicy badania przy ich tworzeniu nie opierali się na żadnym materiale wyjściowym sformułowanym w języku szwedzkim, podczas gdy cechą charakterystyczną streszczenia jest odniesienie do tekstu źródłowego, w tym przypadku w języku szwedzkim. Choć zawierał on stosunkowo niewiele modalizatorów i składał się w większości ze swobodnych wypowiedzi w formie wywiadu, nie można wykluczyć, że osoby piszące streszczenie w pojedynczych przypadkach korzystały ze słownictwa czy konstrukcji tekstu źródłowego, choć w tekstach badanych studentów pojawiło się o wiele więcej modalizatorów niż w tekście wyjściowym i były one użyte w różnych kontekstach. W celu zapewnienia większej swobody w tworzeniu tekstu należałoby jednak w kolejnych badaniach nad użyciem modalizatorów zastosować inny rodzaj tekstu, na przykład tekst argumentacyjny lub ewentual nie streszczenie, ale w oparciu o tekst w języku polskim. W przypadku studentów drugiego roku zadanie streszczenia tekstu polskiego w języku obcym mogłoby okazać się zbyt trudne stąd ćwiczenie tego typu lepiej byłoby przeprowadzić wśród studentów o wyższym poziomie kompetencji językowych.

Studenci na poziomie średnio zaawansowanym zasadniczo potrafią umieścić modalizatory w odpowiednim miejscu w zdaniach zarówno prostych, jak i złożonych, choć większa poprawność charakteryzuje zdania proste i zdania główne w zdaniach złożonych. W zdaniach podrzędnych, których szyk jest najtrudniejszy do opanowania zuwagi na umiejętności przetwarzania struktur morfosynaktycznych, można zauważyć prawidłowe umieszczanie negacji wewnątrzzdaniowej inte. Jednak w odniesieniu do pozostałych modalizatorów 
ich zastosowanie w tego typu zdaniach w połowie przypadków powodowało zaburzenia szyku wyrazów. Przy swobodnej produkcji tekstu należy mieć także na uwadze, że studenci mogli stosować strategię unikania i nie używali modalizatorów w zdaniach, gdzie nie byli pewni ich poprawności gramatycznej, albo stosowali je tylko wtedy, gdy z dużym prawdopodobieństwem mogli uznać, że dany modalizator jest umieszczony prawidłowo. Świadczyć o tym może fakt, że zdecydowana większość modalizatorów użyta została w zdaniach pojedynczych, a wiele zdań podrzędnie złożonych nie zawierało tego typu jednostek leksykalnych. W celu sprawdzenia, czy ich rzadsze użycie w zdaniach podrzędnych jest związane z brakiem umiejętności uczących się w zakresie prawidłowego pozycjonowania, można by przeprowadzić test oceny poprawności gramatycznej. Poza tym badanie można by rozszerzyć o zastosowanie modalizatorów w języku mówionym. Z pewnością rzadkie i dość często niepoprawne umieszczanie modalizatorów w zdaniach złożonych podrzędnie wymaga dalszych badań i powinno zachęcić nauczycieli języka do zwrócenia większej uwagi na ten aspekt podczas zajęć. Jest to możliwe m.in. poprzez wykorzystywanie tekstów, w których modalizatory pojawiają się w takich konstrukcjach syntaktycznych.

\section{BIBLIOGRAFIA}

Åström, M. (2006), Språkporten - för svenska som andraspråk A och B. Lund: Studentlitteratur.

Biber D. i in. (1999), Longman Grammar of Spoken and Written English. Harlow: Longman.

Bolander M . (1988), „Nu jag hoppas inte så mycke”. Om inversion och placering av negation och adverb i svenska som andraspråk, (w:) Hyltenstam K., Lindberg I. (red.), Första symposiet om svenska som andraspråk. Stockholm: Centrum för tvåspråkighetsforskning, s. 203-214.

Bolander M. (2005), Funktionell svensk grammatik. Stockholm: Liber.

Coste D. i in. (2003), Europejski system opisu kształcenia językowego : uczenie się, nauczanie, ocenianie. Warszawa: CODN.

Grochowski M. i in. (2014), Słownik gniazdowy partykuł polskich. Kraków: Polska Akademia Umiejętności.

Hartmann R., Stork F.C. (1976), Dictionary of language and linguistics. London: Applied Science Publ.

Holm B., Nylund E. (1993), Deskriptiv svensk grammatik. Stockholm: Liber.

Hyltenstam K. (1978), Variation in interlanguage syntax. Lund: Department of Linguistics.

Kowal I. (2020), Satsadverbial i svenskundervisningen - en läroboksanalys. "Scandinavian Philology", nr 18(1), s. 56-71. 
Laskowski R. (1999), Zagadnienia ogólne morfologii, (w:) Grzegorczykowa R., Laskowski R., Wróbel H. (red.), Gramatyka współczesnego języka polskiego. M orfologia. Warszawa: Wydawnictwo Naukowe PWN, s. 27-50.

Levy Scherrer P., Lindemalm K. (2008), Rivstart B1 + B2. Textbok. Stockholm: Natur och kultur.

Lindholm H. (1997), Svensk grammatik. Svenska som främmande språk. Lund: Kursverksamhetens förlag.

Lindström E., Lubinska D. (2019), En deskriptiv longitudinell studieav konnektorbruk i nybörjarsvenska hos vuxna inlärare, (w:) Ljung Egeland B. i in. (red.), Klassrumsforskning och språk(ande). Classroom research and language/languaging. Rapport från ASLA-symposiet i Karlstad, 12-13 april, 2018. Papers from the ASLA symposium in Karlstad, 12-13 April, 2018. Karlstad: Karlstads universitet, s. 61-87.

M irowiczA. (1948), O partykułach, ich zakresiei funkcji. „Biuletyn PTJ”, nr 8, s. 134-148. Pienemann M ., Håkansson G. (1999), A Unified Approach toward the Development of Swedish as 12. A Processability Account. "Studies in Second Language Acquisition", nr 21(3), s. 383-420.

Saloni Z. (1974), Klasyfikacja gramatyczna leksemów polskich. "Język polski", nr 14(2), s. 93-101.

Strutyński J. (2002), Gramatyka polska: wprowadzenie, fonetyka, fonologia, morfologia, składnia (wyd. 5). Kraków: Wydawnictwo Tomasz Strutyński. Swan M. (2005), Practical English usage. Oxford: Oxford University Press.

Szober S. (1923), Gramatyka języka polskiego. Lwów-Warszawa: Książnica Polska. Świątkowska M. (2014), O partykułach inaczej. Kilka uwag o problemach terminologicznych, (w:) Bednarczuk L. i in. (red.), Linguistique romane et linguistique indo-européenne : mélanges offerts à Witold Mańczak à I'occasion de son 90e anniversaire. Kraków: Uniwersytet Jagielloński. Instytut Filologii Romańskiej, s. 445-450.

Teleman U. i in. (1999), Svenska Akademiens grammatik. 4, Satser och meningar. Stockholm: Norstedts Ordbok.

Thomson A.J., Martinet A.V. (2001), A practical English grammar. Oxford: Oxford University Press.

Vaakanainen V. (2018), Konnektorbrukets utveckling i finska inlärares L2-svenska,

(w:) Sköldberg E. i in. (red.), Svenskans beskrivning 35: Förhandlingar vid trettiofemte sammankomsten Göteborg 11-13 maj 2016. Göteborg: Göteborgs Universitet, s. 341-353.

WajszczukJ. (2005), 0 metatekście. Warszawa: Katedra Lingwistyki Formalnej UW. 